The Sacred Self 



\title{
THE SACRED SELF
}

A Cultural Phenomenology of Charismatic Healing

\author{
Thomas J. Csordas
}


University of California Press

Berkeley and Los Angeles, California

University of California Press

London, England

Copyright (C) 1994 by The Regents of the University of California

First Paperback Printing 1997

Library of Congress Cataloging-in-Publication Data

Csordas, Thomas J.

The sacred self: a cultural phenomenology of charismatic healing / Thomas J. Csordas.

p. $\mathrm{cm}$.

Includes bibliographical references and index.

ISBN 978-0-520-20884-1

1. Spiritual healing. 2. Pentecostalism-Catholic Church.

3. Pentecostalism-New England. 4. Self. 5. Identification

(Religion) 6. Catholic Church-New England-History-1965- 7. New England-Church history. I. Title.

BT732.5.C86 1994

$234^{\prime} .13-\mathrm{dc} 20$

93-34279

CIP

Printed in the United States of America

$\begin{array}{llllll}12 & 11 & 10 & 09 & 08 & 07\end{array}$

$\begin{array}{lllllll}9 & 8 & 7 & 6 & 5 & 4 & 3\end{array}$

The paper used in this publication meets the minimum requirements of American National Standard for Information Sciences-Permanence of Paper for Printed Library Materials, ANSI Z39.48-1984. @ 